\title{
What is a Guest? What is a Settler?
}

\author{
Ruth Koleszar-Green \\ York University \\ ruthkg@yorku.ca
}

\begin{abstract}
This article gathers together some Traditional Knowledge keepers' understandings concerning the roles and responsibilities of Guests and Hosts. The responsibilities are mapped upon Wampum Belts and in this article include my understanding, as a Haudenosaunee woman. Through discussions with some Knowledge Keepers, examination of the relevant literature, and my own understandings of the issues, I look carefully, at the work of Tuck and Yang (2010) and Lawrence and Dua (2005). I continue with a synthesis of contemporary debates concerning, the underlying complexities of Guests/Settlers roles and responsibilities. I offer differentiations between the descriptive labels in conventional use. My intent is to engage and push non-Onkwehonweh people to challenge their 'taken-for-granted' understandings of their 'rights', and to encourage them to look with fresh eyes at their understandings of their attendant responsibilities.
\end{abstract}

Keywords: Onkwehonwe, Guest/Settler, Indigenous, Wampum

Increasingly, many spaces and events that I have attended over the past few years, on university campuses and in the greater community have been opened with acknowledgements of the Land that the participants are standing on. Many times, the words that are spoken are a thanksgiving to the Nation that is 'hosting' the event on their traditional territory. In such contexts, the speaker usually states that they are a 'guest' on this land.

But what is a guest? What are the rights and the responsibilities that accompany being a guest? In acknowledging the land, have guests done all that they need to do to uphold their responsibilities to the land and the Nations that are treaty holders? What are the differences between settlers and guests?

In looking at the 'Guest' discourse, I turned to the Elders and Traditional Teachers who reside in or around the Toronto area, in order to gather stories and teachings of the proper protocols and engagements that are expected in 'host' and 'guest' relationships. I have been taught the importance of learning from an oral tradition as well as seeking knowledge in written texts. In gathering teachings on Guests, I felt that it was imperative to sit and listen to teachings provided by knowledge keepers. These teachings originate from and span the land, from the east to the west coasts, I spoke to Elders and Traditional Teachers from six different Nations. Even though the stories I heard may differ, the expectations regarding how to treat individuals that are in one's home, community or territory were similar. It is through teaching about hospitality and care that Onkwehonwe ${ }^{i}$ people are taught to treat people who are their guests in their territory. Guests, however, also have responsibilities. 
As a Haudenosaunee person, I start this article by sharing the teachings and learnings that I have received about Wampum Belts and summarize my conversations with Traditional Teachers and Knowledge Keepers from other Nations. I then examine and explore settler discourses and bring this knowledge together with the traditional teachings I have gathered about Guests.

Wampum Belts are woven documents. They have existed prior to contact with Europeans, as a means of recording and passing on agreements. The beads are white, made from Whelk shells; and purple/black, made from the growth rings of Quahog shells. These belts are considered to be living and binding agreements between different groups of Onkwehonwe people or between Onkwehonwe people and guests. The four belts that will be discussed here are "The Dish with One Spoon", “The Hospitality or Welcome Belt", "The Coming of the People with White Faces - A Record Belt", and "The Two Row Wampum" or Guswhenta, in Mohawk. Most of my understandings of these belts come from teachings that I have received over the past few years from Sakoieta and Tewentahawitha ${ }^{i i}$ (Sakoieta and Tewentahawitha, personal communication, September $22^{\text {nd }}, 2013$ ). There is also, a brief description and image in Wampum Belts of the Iroquois by Tehanetorens (1999). I also want to acknowledge that there are many Haudenosaunee thinkers and scholars such as Susan Hill (2017) and Rick Hill (2013) that have explored these Wampum Belts in written form.

My understanding is The Dish with One Spoon is a belt that represents a pre-contact treaty between the Haudenosaunee, and Anishnawbe. It is a long and narrow white belt that has an emblem in the centre to represent a Dish with a beaver tail in it. I have heard it spoken (by knowledge keepers such as Dan Longboat and Rick Hill), that the Dish Wampum has three important teachings on how we, as Onkwehonwe, are to engage with this territory and Mother Earth. The Earth we live on is a dish and we, as people, all eat out of the same dish using the same spoon. It is important as we live our lives, we never take more than we need, we ensure that we leave something in the Dish for others, and we keep the Dish clean.

In my understanding, the idea of The Dish with One Spoon was first introduced by the Great Peace Maker of the Haudenosaunee Confederacy in 1142. When the Peace Maker brought together the 50 Chiefs of the Confederacy, he passed around a dish with beaver tail in it. He taught the chiefs that it was their responsibility to ensure there was enough food for everyone in the circle, meaning they could not take more than their share. He taught them to leave some beaver tail in the dish for others. He taught them to keep the dish clean and not to foul it. As the Dish went around the circle of chiefs, they all used a spoon to serve themselves chunks of already cut up meat as there were to be no knives in the circle. The Peace Maker wanted to ensure the chiefs used a spoon. He did not want the chiefs to bring in shaped weapons that could hurt or harm others. We are also reminded our words can be sharp and used to hurt people. These teachings have travelled with the Haudenosaunee over the past 875 years. In acknowledging all of these teachings, it is also important I acknowledge this is the Haudenosaunee understanding of this Wampum. I respect and honour that the Anishnabe also have a complex and long history with this Wampum. I do want to pay acknowledgment to Chief Tecumseh for bringing the Dish with One Spoon forward as a reunifying Wampum, and to mention the Treaty between the Haudenosaunee and the Anishnabe Confederacies at the completion of the non-Indigenous conflict known as, the War of 1812. It is said that the Dish with One Spoon covers the geographical area known as the Great Lakes water-shed and the St. Lawrence seaway system. As 
this is one of the first treaties of this territory that I live on, it is a starting point for conversations with Guests and settlers.

The Hospitality Wampum Belt is pre-contact. This belt contains certain laws that Chiefs of the Confederacy ${ }^{\mathrm{iii}}$ would use when hosting council meetings and welcoming other people from visiting Nations. It explained the important roles hosts would play when delegates from other Nations would arrive in their territory. An example of the expected hospitality is that "the candidate chief shall furnish together the cooked venison, the corn bread and the corn soup" for it is considered "not good nor honourable for a Chief of the League [to not provide for the people] he has called [together]" (p. 51). As explained by Sakoieta, it is the responsibility of the host to welcome, provide water and food, and offer the best bed. To this day, these responsibilities are still alive and expected in Haudenosaunee homes, communities and Nations. It is expected that a host will have more food and drink than the guest will ever need. It is the host's responsibility to fill the plates, so they are never empty, fill the cups so there is never thirst and offer gifts to every individual (Sakoieta and Tewentahawitha, personal communication, September $22^{\text {nd }}, 2013$ ).

One afternoon, in September of 2013, I was gifted with the opportunity to sit with Sakoieta to learn more about Wampum Belts. As we chatted, he pulled out a Wampum that I had never seen before. He told me that this belt, "the Coming of the White Faces", was a promise made to the Guests. He said that the Haudenosaunee would support the Guests and help them learn to live and thrive on this land. The belt is predominately white with a pattern of angled, wide, purple beads holding up a thin and dotted line of purple beads supported with another wide band of purple beads. This pattern is repeated four times. The wide bands represent the Haudenosaunee and the dotted band represents the newcomers or the Guests (Sakoieta and Tewentahawitha, personal communication, September $\left.22^{\text {nd }}, 2013\right)$. This Wampum Belt is a reminder of the Haudenosaunee pledged to "hold them [the Guests] up so that they did not fall down, that is, showing them how to hunt, to farm and teaching them how to survive and live in this country until they were strong enough to support themselves" (Tehsnetorens, 1990, p. 70). As a Record Belt, I understand it to be a reminder of the promises made. This Record Belt is important to my work as I feel it is a promise that I am attempting to live up to.

There is still a lot of work to be done by the Haudenosaunee to uphold our end of the bargain. Many Guests still need support and help to thrive on this territory. The need for the recommitments and engagement of the Haudenosaunee is not due to the disengagement of the Haudenosaunee, but the result of structure and functions of the Canadian state. The Record Belt is a living testament to the promise that was made however, it has not been fully realized due to the impacts of colonization. It is my understanding we, as Haudenosaunee, still have a commitment to acknowledge and support the individuals, communities and peoples that are newer to this land. In saying this, I am not absolving Guests of their responsibilities; I am acknowledging Wampum Belts document the responsibilities of both parties. I will discuss some of the Guests' responsibilities in the next section.

The fourth belt is famous. It is called Guswhenta in Mohawk or the Two Row Wampum in English. The original Guswhenta is over 400 years old and was accepted as a treaty in 1613 by the Dutch. It is seen today as a symbol of how our relationships should continue to be. This belt is made up of three rows of white beads separated by two rows of purple beads. The purple beads 
run parallel to each other. It is said that the purple beads represent two vessels (one, a canoe and the other a ship) which travel down the same river without interfering with each other or attempting to steer the other vessel. The white beads are to represent Peace, Friendship and Mutual Respect (Sakoieta and Tewentahawitha, personal communication, September $22^{\text {nd }}$, 2013).

In our conversation, Sakoieta tells me that Guswhenta also explains for both parties to come together with Peace, Friendship and Mutual Respect, each group must be operating from these values within themselves. Each of the three white bands of beads has three strings of beads for a total of nine rows of white beads. He teaches me that before Onkwehonwe people and Guests can fully engage in Peace, Friendship and Mutual Respect, they need to be working for these values within each community (Sakoieta and Tewentahawitha, personal communication, September $22^{\text {nd }}, 2013$ ).

The words that Sakoieta and Tewentahawitha shared with me are specific to the Confederacy of the Haudenosaunee; however, the underlying message was about peaceful interactions that respect the autonomy of both Onkwehonwe and Guests. I also had the privilege to speak with Elders and Traditional people from other Nations. The conversations mostly happened as one-on-one meetings in the Teacher's home/office or in my own home. Conversations started with me approaching individuals according to the protocols I have been taught regarding speaking with Elders and Traditional people. As I reached out to people, I explained before we met that I was gathering teachings on Guest/host relationships and I was going to use this information like a literature review for my comprehensive exam ${ }^{\text {iv }}$. I spoke to Kathy Absolon-King, Amanda Thompson and Hilton King from the Anishinabe Nation, Joanne Dallaire and Blu Waters from the Cree Nation, Cyndy Baskin from the Mi'kmaq Nation, and Lee Maracle from the Stolo Nation ${ }^{\mathrm{v}}$. Each individual gave me some amazing gifts and teachings about how to engage and treat Guests. Each also spoke from their viewpoint on the responsibilities that Guests have to Onkwehonwe and to Turtle Island.

The sharing each individual did came from their teachings and worldviews; however, there were many similarities with the teachings that Sakoieta and Tewentahawitha shared with me. All spoke to the importance of sharing food and drink, introductions, and gifts. But the one space of learning that was an opening for all of these teachers and their histories was an understanding, as Kathy named it, of the "authentic intentions" of Guests to engage new education (K. Absolon-King, personal communication, October $9^{\text {th }}, 2013$ ).

Another important conversation, occurred when I was presenting at the $14^{\text {th }}$ Annual Indigenizing the Academy Conference at Queen's University. At that time, I was struggling with the words: non-Aboriginal, settler, colonizer and Canadian, when Lee Maracle, a traditional teacher, writer and member of the Stolo Nation from the Fraser River Valley in British Columbia, gave me a gift. I was struggling to find a word that felt right and acknowledged the relationships I wanted to research. I do not really like the word "Aboriginal"vi , thus to use "nonAboriginal" was uncomfortable. "Settlers" and "colonizers" sound adversarial when I speak them as an Onkwehonwe person. I feel there are already so many assumptions implicit in the term "Canadian", i.e. who is allowed that label; I felt it excluded many other marginalized groups. I did not know how to address the people I wanted to research. Lee reminded me that each Onkwehonwe Nation has teachings on the proper protocols and ways to engage Guests of 
the territory and there are also expectations and responsibilities that go along with being a Guest. From that moment onwards, I knew I would be talking to and referring to Guests of this land; the people on the other side of Guswhenta (L. Maracle, personal communication, February $4^{\text {th }}$, 2012).

One of the very first engagements between European Guests and Onkwehonwe people occurred in 1534 at the Bay of Chaleur, where Cyndy Baskin is from. Cyndy speaks about how when Jacques Cartier landed, he and his crew were approached in friendship by the people there and they were taught how to survive in Mi'kmaq territory. In her territory, hospitality was and still is greatly revered. Further, hospitality included civility. It would have been against Mi'kmaq understandings and worldview to not share, provide and teach Guests all that the Mi'kmaq knew. These interactions included, as much as possible, a reciprocal relationship between teaching and learning. These relationships included, but were not limited to, understanding the Guests' religious ceremonies and sharing traditional Mi'kmaq ceremonies, and teaching Guests to respect the spirits of the animals, and as importantly, to view the land as sacred while living in harmony with it. This understanding of supporting, teaching and sharing with Guests is echoed by all the teachers I spoke with (e.g., C. Baskin, personal communication, September $23^{\text {rd }}, 2013$ ).

Much like the Haudenosaunee Confederacy, the Mi'kmaq Nation made treaties with the French because the French saw them as fully independent Nations that had a territory and constituency to represent. These treaties were, and still are, a means to ensure peaceful coexistence between the Mi'kmaq Nation and the Guests. Cyndy talked about how treaties did not transfer territory, independence or freedoms to the Guests and this was not the intent of the French Guests that signed the treaties (C. Baskin, personal communication, September $23^{\text {rd }}$. 2013).

I was able to sit down again with Lee Maracle, who initially suggested I look into Guest teachings. In our conversation, she spoke about the Entrance Ceremonies from her culture. Guests are expected to explain who they are, where they were coming from, how they got to "this place" and what their intentions are in entering the community. She described a ceremony in which the host community members would respond with their own stories so that the Guests and the hosts had a common understanding of "this place". Lee explained most of this sharing would be done through song. When the hosts felt they understood the intentions of the Guests to be honourable and good, they were allowed to enter the Longhouse/community. Once a Guest has been allowed to enter, they are welcome to return. They are then treated as family. After explaining this to me, Lee laughed and said, "You know, we have never let any government officials into our Longhouses. They do not have good intentions" (L. Maracle, personal communication, October $\left.6^{\text {th }}, 2013\right)$.

Grandmother Joanne Dallaire (Cree, Wolf Clan) reiterates this conversation of intentions as she lays out how she welcomes people into her spaces. She stated that, at first, she is hesitant to open the doors and invite people in. However, as relationships are built and strengthened, she describes how she welcomes Guests; once she is comfortable understanding their intentions, she opens up her home. In offering the Guest food, a drink, a gift and a safe place to be, she also expects to have her space respected and treated like a sacred place. The provisions of food and drinks she provides are in line with hospitality as discussed by Cyndy and Sakoieta.

Grandmother told me being a Guest has just as many responsibilities as being a host. And as with 
many of my conversations, she laughs and says she has no problem reminding her Guests to pick up their cup or plate because there are expectations and responsibilities associated with being a Guest. Being a Guest is just as much work as being a host (J. Dallaire, personal communication, October $\left.7^{\text {th }}, 2013\right)$.

In receiving teachings, one thing that I have learned is I need time to reflect on the words that I hear. My conversation with Hilton King was interesting because he decided to tell me about his recent Fast ${ }^{\text {vii }}$. He spoke about the place he was told to set up camp and fast for four days and nights. Just a short distance outside of the circle in which he sat, were two trees that were rooted very close to each other. The trees were about the same size; however, one tree had grown up straight and the other tree appeared to have grown outward and then upward. The trees, he said, remind him of the work I am doing. I think I have come to understand this teaching as a story of resiliency and natural order. Had the one tree not grown outward and provided a space for the other tree to grow, neither would have thrived. Hilton said the story was like the essence of the Onkwehonwe teachings I was using to ground my work. In the natural environment, plants and animals find ways to be resilient and flourish even under questionable circumstances. Onkwehonwe people and Guests can find ways to flourish when we work together $(\mathrm{H}$. King, personal communication, October $\left.9^{\text {th }}, 2013\right)$.

The teachers all situated their teachings on responsibilities and respecting of protocols. Learning about the diverse protocols of different nations is an important role of a Guest so there can be respectful engagement. Learning protocols is a responsibility.

One of the teachings that I asked each Teacher about was related to what they do when they are in another Nations' territory. I was given very similar answers from everyone. I was told it is expected that when in a new territory, one is to behave and learn the protocols of that territory. As Sakoieta told me, "When you are away from home, you accept the teaching even if it is not your teaching." The protocols of an individual's own Nation are not to be forgotten; however, it is one's responsibility to learn and follow protocols of the hosts. This creates a space where different Nations share teachings and build relationships as the Traditional person and new community share the importance of respecting protocols (Sakoieta, personal communication, September $\left.22^{\text {nd }}, 2013\right)$.

One of the greatest examples of this teaching that I received, in talking to the Traditional people, was around a sacred medicine: Tobacco. Tobacco is one of the first medicines of the Haudenosaunee people. We burn Tobacco in prayer, and it is not something we give to people. However, I made Tobacco ties (small bundles of the medicine tied up in a piece of cloth) to give to Traditional Teachers as per teachings I was given, by Anishinabe teachers. In Anishinabe and Cree teachings, as I have been taught, Tobacco is given by a seeker of knowledge or information as an intentional way to ask for help or guidance. As Wilson and Restoule (2010) discuss, this is not just an intellectual exchange but that "Tobacco works with the spirit" (p. 34).

When I first sat down with each Elder, I decided to ask about offering Tobacco to them. In doing this, I was able to have some very candid conversations about the expectations involved in following the protocols. Traditional people who come from Nations that do not offer/accept Tobacco historically indicated they regularly accept Tobacco from people as it is the proper protocol for the Ongwehonwe people who have lived in this territory from time immemorial. In some of the conversations, the Traditional person and I mutually decided I would not offer 
Tobacco to them (however, I did gift each Traditional person. All of the people I spoke to accepted my non-traditional gift with great thanks) (e.g., Sakioeta, personal communication, September $22^{\text {nd }}, 2013$ and L. Maracle, personal communication, October $\left.6^{\text {th }}, 2013\right)$.

In opening up conversations about following traditional protocols, I was able to hear about the struggles that can occur when Onkwehonwe people travel to other territories. I was told stories about how when Onkwehonwe people from different territories visit, they have been confused at first by the offering of Tobacco. In respecting the protocol of the territory and the teachings of their host, in the end, the Guests, usually accept the medicine. Accepting Tobacco might not have a cultural significance to some Nations; however, if it does have significance to the individual or group that is offering the Tobacco, the protocols of the host Nation are to be followed. In accepting the gift of Tobacco, the Onkwehonwe Guest is demonstrating a respect for the protocols of the Nation they are visiting and are respecting the host.

All of this being said, when an Onkwehonwe person travels to other Onkwehonwe Nations, the offering of Tobacco may occur due to the adherence of the teachings of the individual doing the offering. It would then be the responsibility of the individual or Nation offering the Tobacco to explain the protocol of responsibly in accepting the Tobacco. As Blu explained, "If you are a Guest in a space, it is okay to do it your way, but you need to explain your way" (B. Waters, personal communication, January $\left.7^{\text {th }}, 2015\right)$. The adherence to protocols of other Nations also creates a space for the visiting Onkwehonwe to receive a teaching on being a Guest in another Onkwehonwe territory (Sakoieta, personal communication, September 22 ${ }^{\text {nd }}$, 2013 and L. Maracle, personal communication, October $18^{\text {th }}$, 2013).

In outlining the teachings that I have gathered about being a responsible and respectful Guest, I have realized there need to be distinctions made between how I understand two words. In most of my writing, I use the word Guest to describe people that have joined Onkwehonwe people on Turtle Island. However, there are quite a few scholars, activists and allies that refer to themselves as settlers. I have been questioned as to why I do not use the word settler and challenged to think more about the implications of this.

I have thought a lot about this question. At first the answer was simple: when I use settler, I sound angry and the perceived anger makes it hard for non-Onkwehonwe people to hear. However, after gathering these stories and living these teachings, I realized there are many people that want to engage in dialogue and discussion about healthy Host/Guest responsibilities. I am not denying there are many people on this land who engage in such ways and further, adopt the means which demonstrate domination and violent disregard for Onkwehonwe people. There are also people on this land that are ignorant about: Onkwehonwe people, their culture, history and current struggles. It is my belief that all people on this land need to know and understand the treaty rights and attendant responsibilities of living with this land.

In reading works such as Tuck and Yang (2012), and Simpson (2010) to name a few, I do not believe that such authors are telling every non-Onkwehonwe person to pack their bags and 'move back to where ever they came from'. There is talk of decolonization and rematriation/ repatriation of Land ${ }^{\text {viii }}$ but what can that look like in a settler colony. (A space where the colonizers intentionally moved to, without the intent of ever returning to the 'mother' land, or planned the creation of a new 'mother' land)? Stating we 'want to return to pre-contact days' is impossible. I feel that in demanding rematriation of Land, we are actually talking about

Cultural and Pedagogical Inquiry, Fall 2018, 10(2), pp. 166-177

ISSN 1916-3460 @ 2018 University of Alberta

http://ejournals.library.ualberta.ca/index.php/cpi/index 
stewardship; speaking of resource protection and sharing in a way that is supportive of Onkwehonwe sovereignty and National determination.

In my understanding, Wampum being a living document, Guswhenta talks not only to those who accepted Guswhenta initially, but also to everyone who has since entered Onkwehonwe territories. I need to acknowledge not all individuals and communities that are on this Land chose to be here. Slavery, exploitation, and colonial histories, as well as current realities across the globe, have impacted settlement. The ways that the intentions of the 'original' treaty makers engage with newer Guests are also affected. As Malissa Phung (2011) states in her response to Lawrence and Dua (2005), "I am interested in invoking an anti-colonial conceptualization of the term "settler" that both recognizes non-Indigenous complicity in Canada's ongoing colonial project and stands in solidarity with the decolonization projects of Indigenous people" (p. 296). White supremacy, racism, and the continual marginalization of people of colour impact how communities access and engage in relation to Guest identities. The current Canadian state has created policies and laws that contravene the teachings of Guswhenta; further, colonial histories and the resulting racisms all need to be acknowledged. Such acknowledgement does not erase the complexities of Guests' responsibilities but adds more layers to identity development.

I have seen a shirt that is usually sold at Powwow and Onkwehonwe gatherings. The statement, "Original Landlord" with a picture of Turtle Island is on the front. On the back, is the challenge, "Time to pay the rent". Even though I disagree that Onkwehonwe people 'owned' the Land, we have had a relationship to/with the Land and been its stewards since time immemorial. The relationship is centred on respect and responsibility. The notion that the Land is 'rented' and 'not owned' is an important distinction to allow one's understanding, of the need for rematriation.

All Lands that are held by the Crown or worse, held in trust by the Crown (here, I am alluding to the reserve system), need to be immediately placed under the control of the Nations that are the treaty holders in that specific area. Projects and 'developments' that are planned on the Lands, need to be controlled and navigated by Onkwehonwe communities, instead of merely consulting the communities. (I do not suggest placing the lands in the hands of the band chief and counsel system because they are mechanisms of control introduced by the colonial government. I would like to see the responsibilities taken up by the Confederacy Chiefs and Clan Mothers).

Tuck and Yang (2012) discuss how settlers, in moves to innocents (citing Fellows and Razak, 1998), attempt to situate themselves as the occupiers who have connections to, or rights to the Land. The authors argue convincingly, that decolonization is not a metaphor. We cannot decolonize systems and structures that are inherently fraught with colonial and settler privileges. In considerable depth, the authors explicate the settlers' six moves or positions utilized to expunge themselves of 'guilt'. These moves include: Firstly, settler nativism, the settler attempts to absolve themselves of any colonial harm by claiming Onkwehonwe heritage (p. 10). Secondly, fantasizing adoption, the settler claims to be a good, white person who learns the ways of the Onkwehonwe and is adopted into the 'tribe' (p. 13). Thirdly, colonial equivocation, the claim that we are all from an oppressed population. Such experience creates an equal line of oppression (p. 17). Fourthly, conscientization, the claim that through building critical consciousness, and 
'decolonizing the mind', settlers can move to a place of righteousness and innocence (p. 19). Fifthly, the practices of: 'at risking' or 'asterisk-ing' Onkwehonwe people and the erasure of Onkwehonwe people in research and policies due to their 'at-risk' status, or because of their statistically, insignificant numbers. Accordingly, perpetuating the idea that addressing Onkwehonwe issues are not critical matters (p. 22). Sixthly, re-occupation and urban homesteading as seen through the Occupy movement that had little-to-any critique regarding, the continual occupation of Onkwehonwe territories and the return to 'pioneer homesteading' in urban centres (p. 23).

Lawrence and Dua's article "Decolonizing Anti-Racism" (2005), challenges the erasure of Onkwehonwe Peoples through the tenets of anti-racism discourses. Inadvertently, Lawrence and Dua work provides me with the space and ideas to differentiate between Guests and Settlers. In mapping the ways in which anti-racism discourses and actions, support settlers of colour who apply colonial constructs to Onkwehonwe populations, the authors assert the following: 1) Onkwehonwe Peoples' existences are erased because racism (and anti-racism) theories exclude their unique experiences with racialization. 2) The failure of people with diasporic identities to acknowledge that there were and are multiple colonial projects in which settlers of colour benefit from the settlement of Onkwehonwe lands. 3) The stories of slavery and diasporic peoples, in effect, write over and obscure Onkwehonwe colonial stories. 4) Decolonial and anti-racism politics are seen as being equal. 5) Colonial nationhood (i.e. a Canadian identity) delegitimizes Onkwehonwe nationhood (i.e. Mohawk citizenry) (Lawrence and Dua, 2005, p. 128).

By thinking and reflecting on the two writings, by Tuck and Yang (2012) and Lawrence and Dua (2005), I have defined working (or work-in-progress) distinctions between the categories which allow me to differentiate between a settler and a guest. Accordingly, a settler is an individual who states that they are on stolen land. They might know whose 'traditional territory' they are on, and they might wish to be a good ally, but usually a settler's intentions stop there!

A Guest, on the other hand, understands through a reflexive process that as a Guest they have responsibilities to learn about rematriation of the land (including for example, stewardship and possession are foundational to environmental revitalization). The Guest learns the history and current story of the land that they are Guests on! They politicize that understanding. Finally, they listen to and learn protocols which do not appropriate but unsettle the privilege of ignorance. The Guest is an active and respectful individual who recognizes their privilege and uses that privilege in a way that does not centre them self but centres the community.

A settler is an individual that engages with Onkwehonwe communities either in a superficial way. There are numerous ways that superficial engaging can occur, for example, participating in relations that does not unsettle their privilege but allows them to appear in solidarity. It can also be approaching individuals and/or communities with an agenda that will centre equality (and not equity), or equate the settler's reality to the Onkwehonwe reality, either at individual levels (as a person) or at community levels (we all have faced oppression).

Decolonization is not a metaphor. There needs to be real implications and directives to ensure that 'settlers' move towards becoming 'Guests': meaning, people who are on this land, who are not leaving, or being removed. They respect that there are protocols that have existed since time immemorial that need to be followed. Unfortunately for many Onkwehonwe People, 
nations, and communities, the transition from settler (those that are starting to learn) to Guests (those that are unsettling privilege) will fall upon Onkwehonwe people to educate, re-educate and inspire Guests to learn.

The distinctions between the roles of a 'settler' and a 'Guest' are not all encompassing of all peoples that reside on Turtle Island/North America. In discussing both of these groups, I have intentionally not discussed individuals and groups of people that are not critically (or even uncritically) examining their occupation of this territory. I acknowledge that there are many people that live here but do not even contemplate their relationships to Onkwehonwe peoples. I know that there are a vast number of educational resources that people could access, but I also know that many individuals are attempting to survive. The decolonizing project is not even within their consciousness.

The individuals who are not conscious of their settler privilege are people who need to be brought into the conversation. I see them as ignorant. These people would benefit from conversations with settlers, Guests and Onkwehonwe people. There is also another group of people whom I am not addressing in this paper. I am not engaging in conversation with people who are openly hostile towards Onkwehonwe liberation. I see these people as intolerant. This last group are not mine to educate; it is the work of the Guest to open up these dialogues. It is dangerous and damaging for Onkwehonwe people to educate people who are intolerant. I am not saying the ignorant and the intolerant people should not be educated, but I am distinguishing between the roles I can/want to adopt and the responsibilities of Guests who take part in such educational activities.

So back to the question I posed!

What is a Guest?

A Guest is an individual that is in relationship to the Land in a way that supports stewardship and not ownership. A Guest is an individual who is in relationship with Onkwehonwe communities and who respects reciprocal engagement. The rights that go along with being a Guest are to be on the territory, and the responsibilities of being a Guest are to support Onkwehonwe nations by centring and supporting the traditional (pre-contact) and contemporary (post-contact) treaties.

There is a responsibility to: know the colonial stories and to support the resistance, under the leadership of Onkwehonwe people to continuing colonial projects. In acknowledging the land, Guests need to do more than offer words; they need to offer actions that support the sovereign Nations whose territories they are Guests on. Finally, a Guest is someone who is traveling down this 'river of life' in their own vessel. At the same time, a Guest actively engages Onkwehonwe people with a reciprocal process of Peace, Friendship and Mutual Respect. 


\section{Endnotes:}

${ }^{i}$ This article intentionally does not utilize the word 'non-Aboriginal' to describe the people that have joined Onkwehonwe people on Turtle Island. There is a body of literature that discusses the issues with the word "Aboriginal" (please see Freeman, 2011, Schertow, 2008).

${ }^{\text {ii }}$ Haudenosaunee longhouse names, such as Sakoieta or Tewentahawitha, are only given to one individual at a time. There is currently no other person named Sakoieta because each Longhouse and each clan has a set of names that the Faith Keepers hold. When a child is born, they are given a name for life. When that life is over, the name is returned to the Faith Keepers to give to another clan member. Sakoieta is the only name that he needs to use, as a 'last name' is redundant due to cultural protocols on naming.

iii In saying the Chiefs of the Confederacy, I am speaking of the 50 chiefs that make up the Five Nations of the original Haudenosaunee Confederacy. These 50 chiefs are foundational to the political, social, and cultural understanding of the Haudenosaunee. The sixth nation, Tuscarorans do not have Chiefs at the Council Fire.

${ }^{\text {iv }}$ I have returned to each of these teachers and requested if I could include the teaching that they shared earlier. I was given consent.

${ }^{v}$ I will refer to Traditional Teachers and Elders how I would refer to them in the community. I would call these people by their first names mostly and would not address them by their academic titles or by their last name.

${ }^{\text {vi }}$ The term Aboriginal is not a term that Onkwehonwe Nations have given ourselves. It is a term that has been legislated by federal governments as part of our identities.

${ }^{\text {vii }}$ Fasting is a ceremony where an individual will spend time alone in a sacred circle out on the land without food or water for a specific number of days (usually 1-4 days) to pray, dream, celebrate, and give thanks for Creation.

viii In using the word Land, I am acknowledging how Tuck and Yang (2012) short form "land/water/air/ subterranean earth" (p. 5) into Land and I am following their example. 


\section{References}

Freeman, B. (2011). Indigenous Pathways to anti-oppressive practice. In D. Baines (Eds.), Doing anti-Oppressive practice: Building transformative politicized social work, $2^{\text {nd }}$ ed. (pp. 116131). Halifax: Fernwood Publishing.

Hill, R. (2013). Talking Points on History and Meaning of the Two Row Wampum Belt. Retrieved from: http://honorthetworow.org/wp-content/uploads/2013/03/TwoRowTalkingPoints-Rick-Hill.pdf

Hill, S. (2017). The Clay we are made of: Haudenosaunee Land tenure on the Grand River. Winnipeg, University of Manitoba Press.

Koleszar-Green, R. (2016). Understanding your education: Onkwehonwe and Guests responsibilities to Peace, Friendship and Mutual Respect. Retrieved from: https://tspace.library.utoronto.ca/bitstream/1807/73051/1/Koleszar-Green_Ruth_201606_PhD_thesis.pdf

Lawrence, B. and Dua, E. (2005). Decolonizing Antiracism. Social Justice, 32(4), 120-143.

Phung, M. (2011). Are people of colour settlers too? In A. Mathur, J. Dewar and M. DeGange (Eds.), Cultivating Canada: Reconciliation through the lens of cultural diversity (pp. 289298). Ottawa: Aboriginal Healing Foundation.

Schettow, J. A. (2008). Anishnabek outlaw term 'Aboriginal'. Intercontinental Cry. Retrieved from: https://intercontinentalcry.org/anishinabek-outlaw-term-aboriginal/

Tehanetorens. (1999). Wampum Belts of the Iroquois. Summertown: Book Publishing Company.

Tuck, E. and Yang, K. W. (2014). Unbecoming Claims: Pedagogies of Refusal in Qualitative Research. Qualitative Inquiry, 20(6), 811-818.

Wilson, D. D. and Restoule, J. P. (2010). Tobacco Ties: The relationship of the sacred to research. Canadian Journal of Native Education, 33(1), 29-45. 